\title{
Tissue- and development-specific glycosylation states of the natriuretic peptide receptors guanylyl cyclase-A (GC-A) and GC-B
}

\author{
Dieter Müller*, Mirjam Hildebrand, Jörn Lübberstedt, Ralf Middendorff \\ From 5th International Conference on cGMP: Generators, Effectors and Therapeutic Implications \\ Halle, Germany. 24-26 June 2011
}

\section{Background}

The natriuretic peptides (NPs) atrial NP (ANP), B-type NP (BNP) and C-type NP (CNP) elicit cellular effects by binding to transmembrane proteins with guanylyl cyclase (GC) activity, referred to as GC-A (representing the common receptor for $\mathrm{ANP}$ and $\mathrm{BNP}$ ) and $\mathrm{GC}-\mathrm{B}$ (the CNP receptor). GC-A and GC-B are structurally closely related proteins with very similar cDNA-deduced molecular masses in the range of $115 \mathrm{kDa}$, but their native molecular weights are significantly (by up to $20 \mathrm{kDa}$ ) higher due to glycosylation.

Differential glycosylation of cell surface receptors can affect folding, trafficking, ligand binding and/or agonistinduced signal transduction. Moreover, specific temporal expression patterns of carbohydrate structures are frequently involved in developmental processes. Hitherto, however, the glycosylation states of GC-A and GC-B in vivo are largely unknown, since currently available data are based to a great extent on studies with receptor-transfected cell lines.

This investigation aimed to characterize the sizes and posttranslational modifications of native GC-A and GC$B$ in different tissues of adult rats and mice. Based on increasing evidence for specific activities of NPs and their receptors in the developing brain (1-3), we examined the glycosylation of GC-A and GC-B during postnatal brain development.

\section{Methods and results}

Western blot (as well as receptor/ligand crosslinking) experiments and treatments with carbohydrate-digesting enzymes served to investigate the sizes and

\footnotetext{
* Correspondence: hans-dieter.mueller@anatomie.med.uni-giessen.de Institute of Anatomy and Cell Biology, University of Giessen, Germany
}

posttranslational modifications of the two receptors. Due to marked tissue-specific differences in N-linked glycosylation, mean apparent molecular masses of both rat and mouse GC-A range from $119 \mathrm{kDa}$ in brain to values between 124 (lung) and 132 (heart) $\mathrm{kDa}$ in peripheral tissues. The reduced glycosylation in brain seems to be central nervous system (CNS)-specific, since the pituitary, which contains both CNS and CNS-unrelated tissue, co-expresses the CNS-typical (119 kDa, reference: olfactory bulb) and the peripheral (up to $130 \mathrm{Da}$ ) forms of GC-A.

GC-B sizes differed in the same manner between peripheral organs, indicating equal tissue-dependent influences on oligosaccharide processing at GC-A and GC-B. A higher (by $3 \mathrm{kDa}$ ) total amount of $\mathrm{N}$-linked carbohydrates suggests usage of an additional consensus $\mathrm{N}$-glycosylation site (7 instead of 6 in the case of GC-A). The existence of region-specific GC-B size variants in cerebellum and olfactory bulb discriminates this receptor from GC-A in the adult brain.

Both GC-A and GC-B (but not two other glycosylated membrane proteins examined) are hyperglycosylated at $\mathrm{N}$-linked sites during early postnatal brain development. At postnatal day 1 , the vast majority of GC-B (but not GC-A) contain additionally an O-linked carbohydrate modification.

Affinity labelling and membrane GC assays did not reveal marked glycoform-associated effects on ligand binding or agonist-induced cGMP production.

\section{Conclusion}

The data uncover tissue-, development- and receptorspecific glycosylation states. Functional consequences remain to be elucidated. 


\section{References}

1. DiCicco-Bloom E, Lelièvre V, Zhou X, Rodriguez W, Tam J, Waschek JA: Embryonic expression and multifunctional actions of the natriuretic peptides and receptors in the developing nervous system. Dev Biol 2004 271:161-175

2. Cao L-H, Yang XL: Natriuretic peptides and their receptors in the central nervous system. Prog Neurobiol 2008, 84:234-248.

3. Müller D, Hida B, Guidone G, Speth RC, Michurina TV, Enikolopov G, Middendorff R: Expression of guanylyl cyclase (GC)-A and GC-B during brain development: Evidence for a role of GC-B in perinatal neurogenesis. Endocrinology 2009, 150:5520-5529.

doi:10.1186/1471-2210-11-S1-P52

Cite this article as: Müller et al: Tissue- and development-specific glycosylation states of the natriuretic peptide receptors guanylyl cyclase-A (GC-A) and GC-B. BMC Pharmacology 2011 11(Suppl 1):P52

\section{Submit your next manuscript to BioMed Central} and take full advantage of:

- Convenient online submission

- Thorough peer review

- No space constraints or color figure charges

- Immediate publication on acceptance

- Inclusion in PubMed, CAS, Scopus and Google Scholar

- Research which is freely available for redistribution

Submit your manuscript at www.biomedcentral.com/submit 